ISSN 1991- 8690

الترقيم الدولي 8690 - 1991

Website: http://jsci.utq.edu.iq

Email: utjsci@utq.edu.iq

\title{
Detection of Norovirus in stool samples by RT-PCR from under five years age children hospitalized for acute gastroenteritis in Basrah, Iraq
}

\author{
Hazim T. Thwiny ${ }^{1}$ \\ Hassan J. Hasony ${ }^{2}$ \\ ${ }^{1}$ Department of Microbiology. College of Veterinary Medicine_ University of Basrah_. Basrah/ Iraq \\ ${ }^{2}$ Department of Microbiology. College of Medicine. University of Basrah. Basrah/ Iraq \\ E-mail: hazimt@yahoo.com
}

\section{Abstract}

Human noroviruses are the leading cause of non-bacterial gastroenteritis in children worldwide. The objectives of this study are to determine the frequency and importance of norovirus in diarrheal illness among children below 5 years of age and to investigate the most affected age, seasonal distribution and the major clinical symptoms associated with norovirus infections; 400 stool samples (200 symptomatic cases and 200 asymptomatic healthy children) were investigated during the period from March 2011 to March 2012.Norovirus was detected in 8\% of symptomatic children whereas all the control groups were norovirus negative. Norovirus was highly prevalent among children of 18-23 months of age $(\mathrm{P}=0.05)$. Noroviruses were continuously detected throughout the year except in May and October, but the principle peaks of detection were in November. The most common clinical symptoms beside diarrhea observed among norovirus infected children were vomiting (94\%), fever (69\%), dehydration (50\%) and abdominal pain found in $31 \%$.

Keywords: norovirus, children .

\section{الكثف عن فيروس النورو في عينات البراز بواسطة تقية تفاعل البلمرة المتسلسل العكسي في الاطفال الاثل من خمسة سنوات من العمر الراقدين في المستشفيات والذين يعانون من التهاب المعدة والامعاء الحاد في البصرة، العرلق

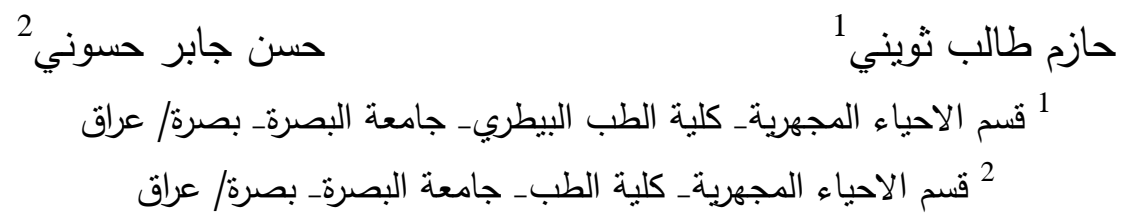

تعتبر فيروسات النورو الخاصة بالانسان مسببا رئيسيا لالتهاب المعدة والامعاء الحاد الغير بكتبرية على مستوى العالم. اهداف هذه الدراسة تحديد اهمية وتكرار فيروس النورو بين الاطفال المصابين بحالات اسهال وتقل اعمارهم عن خمسة سنوات، لتحديد العمر الاكثر تعرضا للمرض، الانتشار الموسمي للمرض والعلامات الرئيسية المصاحبة للاصابة. تم فحص التصنية 400 عينة من البراز (200 من الحالات المرضية و 200 من الحالات الغير مرضية) خلال الفترة من اذار 2011 الى اذار 2012. كانت نسبة وجود الفيروس هي 8\% في الاطفال الذين تظهر عليهم علامات سريرية، بينما في مجموعة السبطرة لم يتم الكثف عن الفيروس فيها. الفيروس كان اكثر شيوعا في الاطفال بعر 18-23 شهر (P=0.05). اما بالنسبة للانتشار الموسمي للمرض، فقد تم الكثف عن الفيروس في كل اثهر السنة ما عدا شهري ايار وتشرين الاول وان الاصابات الاكثر كانت في شهر تشرين الثاني. اهم الاعراض السريرية بجانب الاسهال بالاطفال المصابين بالفيروس كان التقئ بنسبة 94\%، الحمى بنسبة 69\%، الجفاف بنسبة 50\%، والم في البطن بنسبة 13\% الكلمات المفتاحية:نوروفايروس،الاطفال. بجابل 


\section{Introduction}

Human noroviruses have been recognized as the major cause of acute non-bacterial diarrhea outbreaks all over the world, and the second most frequent cause of viral diarrhea in children in developing countries. Noroviruses are also the leading cause of acute non-bacterial gastroenteritis in developed countries. It is estimated that approximately $10 \%$ of sporadic viral gastroenteritis and $45-97 \%$ of outbreaks of non-bacterial gastroenteritis are attributed to norovirus infection worldwide ${ }^{1,2}$. Noroviruses are the frequent cause of sporadic cases and also outbreaks of acute gastroenteritis in children and adults ${ }^{3,4}$ particularly in semi-closed environments such as schools, cruise ships, hospitals and residential homes. Introduction of Norovirus in a community or population may be followed by additional spread of the disease because of its highly infectious nature, resulting in a large number of secondary infections, up to $50 \%$ of contacts $^{6}$. Studies have demonstrated seasonal ${ }^{7}$ and /or geographical differences ${ }^{8,9}$. The development of reverse transcriptase polymerase chain reactions (RTPCR) has greatly enhanced the identification of these viruses. RT- PCR is one of the most sensitive methods for norovirus detection based on the amplification of DNA from the viral $\mathrm{RNA}^{10}$. The results observed in a study in Germany after testing 244watery stool samples from 2 gastroenteritis outbreaks by EM, ELISA and RT-PCR, where in case of RT-PCR had the highest sensitivity $(94.1 \%)$ followed by EM $(58.3 \%)$ and ELISA $(31.3 \%)^{11}$, therefore the molecular techniques are mostly used ${ }^{12}$. This study aimed on the investigation of norovirus infection among less than five years of age children with acute gastroenteritis and healthy children and determination of the most affected age, seasonal distribution and the major clinical symptoms associated with norovirus infections.

\section{Materials and Methods}

A total of 400 fecal specimens were collected from infants and children under five years of age in the city of Basrah, south of Iraq during one year (March 2011March 2012): 200 stool specimens were collected from hospitalized children (including 105 male and 95 female) suffering from acute gastroenteritis admitted to Basrah Hospital for Obstetric and Child (this hospital is a major referral hospital in Basrah city). The remaining 200 stool specimens were collected from nondiarrhea healthy children (including 94 male and 106 female) at $\mathrm{Al}$ Furdos kindergarten and nursery, Al Zohor kindergarten and nursery, and Baraem Al Amal kindergarten and nursery were studied as a control group. Informed verbal consent was obtained from parents/ caregiver of participating children before collecting the samples.A standard structured questionnaire was used to obtain the information regarding age, sex, season, clinical manifestations (diarrhea, fever, abdominal pain and dehydration) and type of feeding (breast, bottle or mixed feeding) for each case. Study extends from March to February. According to WHO's recommendation, all children were classified in specific age groups $(0-2,3-5,6-8$, 9-11, 12-17, 18-23, 24-35, and 36-48 months) 13.

Suspension of $20 \%(\mathrm{w} / \mathrm{v}$, for the solid sampleand $\mathrm{v} / \mathrm{v}$, for the liquid sample) of each stool specimen was prepared in $10 \% \mathrm{NaCl}$, after vigorously mixing, the stool suspension was clarified by centrifugation at 8000 $\mathrm{rpm}$ for $20 \mathrm{~min}$ at $4 \mathrm{C} 14$. The resulting supernatants were collected and stored at $-20{ }^{\circ} \mathrm{C}$ until use for nucleic acid extraction. One stool specimen was collected from each child. Viral Nucleic acid (RNA genomes) was extracted from $200 \mu \mathrm{l}$ of supernatant of the stool sample using a spin-column technique, according to the instructions given in the insert of the QIAamp MinElute virus spin kit .Viral nucleic acid was then recovered in $100 \mu \mathrm{l}$ of elution buffer. All the extracted viral nucleic acid examined by Nano drop instrument in order to determine the concentration of viral RNA.

Oligonucleotide Primers for PCR Amplification of Norovirus

\begin{tabular}{|c|c|c|c|c|}
\hline vinus & Primer a & Sequence b & $\begin{array}{c}\text { Nucleotide } \\
\text { position }\end{array}$ & $\begin{array}{c}\text { Amplicon size } \\
\text { (111) Reference: }\end{array}$ \\
\hline \multirow{2}{*}{ Norovinus } & NI-F & 5-GAATCCATCGCCCACTGGCT-3 & 4756-4776 & Green et a 1 199539 \\
\cline { 2 - 4 } & E3-R & 5-ATCTCATCATCACCATA-3 & $4867-4851$ & \\
\hline
\end{tabular}

Horizontal agarose gels were used for analysis of DNA after RT-PCR, or PCR amplification. The concentration of agarose used was 2\%; gels are prepared as percentage weight/volume solutions. Thus, a $2 \%$ gel is $2 \mathrm{~g}$ agarose in $100 \mathrm{ml}$ buffer, $8 \mu \mathrm{l}$ of the final PCR product were loaded on to $2 \%$ agarose gel containing ethidium bromide $(0.2 \mu \mathrm{g} / \mathrm{ml})$. DNA molecular weights were determined by comparison with a 100 bp DNA ladder. Samples showing a specific amplicon were considered as positive. Statistical Package for Social Science (SPSS) version 15 software was used to analyze the data. Chi- square (X2) test was used to assess the significance of differences between groups and variables. $\mathrm{P}$ value less than 0.05 was considered to 
be statistically significant and $\mathrm{P}$ value less than 0.01 considered as highly significant.

\section{Results}

Norovirus was detected in $8 \%$ of cases. Control group showed negative results to norovirus (Table-1)

Table-1: Incidence of human norovirus among under 5 years age children

\begin{tabular}{|c|c|c|c|c|}
\hline \multirow{2}{*}{ Type of virus } & \multicolumn{2}{|c|}{ Diarrheal group } & \multicolumn{2}{c|}{ Control group } \\
\cline { 2 - 5 } & $\begin{array}{c}\text { No. of +ve cases/ } \\
\text { No. of tested cases }\end{array}$ & $\%$ of Positive & $\begin{array}{c}\text { No. of +ve } \\
\text { cases/ No. of } \\
\text { tested cases }\end{array}$ & $\%$ of Positive \\
\hline Norovirus & $16 / 192$ & $8 \%$ & $0 / 122$ & $0 \%$ \\
\hline
\end{tabular}



Agarose gel electrophoresis demonstrating Norovirus. Lane 1 and 2 represent tested sample that positive for Norovirus. Lane M, 100 bp DNA Ladder marker. (2\% agarose, 100v for 30min) The sex and age distribution of Norovirus infection is shown in Table -2 . Of 16 positive samples, $9(9 \%)$ specimens belonged to male and $7(8 \%)$ to female patients, this difference was not significant $(\mathrm{P}>0.05)$. The age groups analysis revealed that Norovirus infection was among children with age $1-<3$ years, norovirus infection was more prevalent in children of ages 18-23 months $(\mathrm{P}=0.05)$ (Table -2). Norovirus, which occurred in relatively small numbers, involved $8 \%$ of the stool samples studied. All the samples of healthy control group were norovirus negative.
Table- 2: Age and sex distribution of Norovirus-positive in diarrheal group of children under 5 years old

\begin{tabular}{|c|c|c|}
\hline Variable & \multicolumn{2}{|c|}{ Diarrheal group } \\
\hline Age (months) & $\begin{array}{c}\text { No. of +ve cases / No. of } \\
\text { tested cases }\end{array}$ & $\%$ of +ve cases \\
\hline $0-2$ & $0 / 19$ & $0 \%$ \\
\hline $3-5$ & $0 / 19$ & $12 \%$ \\
\hline $6-8$ & $3 / 26$ & $14 \%$ \\
\hline $9-11$ & $4 / 28$ & $10 \%$ \\
\hline $12-17$ & $3 / 29$ & $17 \%$ \\
\hline $18-23$ & $5 / 30$ & $5 \%$ \\
\hline $24-35$ & $1 / 22$ & $0 \%$ \\
\hline $36-48$ & $0 / 19$ & $9 \%$ \\
\hline Sex & & $8 \%$ \\
\hline Male & $9 / 101$ & $8 \%$ \\
\hline Female & $7 / 91$ & \\
\hline Total & $16 / 192$ & $0 \%$ \\
\hline
\end{tabular}

Age groups $X^{2}=20 \mathrm{df}=7 \mathrm{P}=0.05 \operatorname{Sex} X^{2}=0.06 \mathrm{df}=1$ $\mathrm{P}>0.05$

The seasonal distribution of Norovirus infection was as follows: $10 \%$ in winter, $10 \%$ in autumn, $9 \%$ in summer, and the lowest incidence were $4 \%$ in spring $(\mathrm{p}=0.05)$ (Table-3). Norovirus were continuously detected throughout the year except in the months of May and October, but the principal peaks of detection were in November.

Table -3: Distribution of Norovirus in diarrheal group of children under 5 years old in different season

\begin{tabular}{|c|c|c|}
\hline \multirow{2}{*}{ Season } & \multicolumn{2}{|c|}{ Diarrheal group } \\
\cline { 2 - 3 } & $\begin{array}{c}\text { No. of +ve cases / No. of } \\
\text { tested cases }\end{array}$ \\
\hline Spring & $2 / 47$ & \% of +ve cases \\
\hline Summer & $4 / 47$ & $9 \%$ \\
\hline Autumn & $5 / 49$ & $10 \%$ \\
\hline Winter & $5 / 49$ & $10 \%$ \\
\hline Total & $16 / 192$ & $8 \%$ \\
\hline
\end{tabular}

Age groups $X^{2}=20 \mathrm{df}=7 \mathrm{P}=0.05 \mathrm{Sex} \mathrm{X}^{2}=0.06 \mathrm{df}=1$ $\mathrm{P}>0.05$

In Norovirus gastroenteritis; vomiting was the most common feature and was observed in $94 \%$ of patients while fever was $69 \%$. Dehydration caused by Norovirus gastroenteritis was found in about $50 \%$ of patients and abdominal cramp (31\%) was not frequent in these patients (Table-4). Vomiting (94\%) was occurred at higher rate in norovirus- positive children $(\mathrm{p}=0.01)$, compared with the rate of vomiting in diarrheal cases negative to Norovirus. 
Table -3: Distribution of Norovirus in diarrheal group of children under 5 years old in different season

\begin{tabular}{||c|c|c||}
\hline \multirow{2}{*}{ Season } & \multicolumn{2}{|c||}{ Diarrheal group } \\
\cline { 2 - 3 } & $\begin{array}{c}\text { No. of +ve cases / No. of } \\
\text { tested cases }\end{array}$ & $\%$ of +ve cases \\
\hline Spring & $2 / 47$ & $4 \%$ \\
\hline Summer & $4 / 47$ & $9 \%$ \\
\hline Autumn & $5 / 49$ & $10 \%$ \\
\hline Winter & $5 / 49$ & $10 \%$ \\
\hline Total & $16 / 192$ & $8 \%$ \\
\hline
\end{tabular}

$\mathrm{X}^{2}=19.5 \mathrm{df}=3 \mathrm{P}=0.05$

In Norovirus gastroenteritis; vomiting was the most common feature and was observed in $94 \%$ of patients while fever was $69 \%$. Dehydration caused by Norovirus gastroenteritis was found in about $50 \%$ of patients and abdominal cramp (31\%) was not frequent in these patients (Table-4). Vomiting (94\%) was occurred at higher rate in norovirus- positive children $(\mathrm{p}=0.01)$, compared with the rate of vomiting in diarrheal cases negative to Norovirus.

Table-4: Distribution of clinical symptoms in diarrheal children due to norovirus

\begin{tabular}{|c|c|c|c|c|c|}
\hline \multirow[t]{2}{*}{ Type of vinus } & \multirow[t]{2}{*}{ No. of cases } & \multicolumn{4}{|c|}{ Symptoms } \\
\hline & & $\begin{array}{l}\text { Vomiting } \\
\text { No. } \%\end{array}$ & \begin{tabular}{l}
\multicolumn{2}{c}{ Fever } \\
$N_{0} \%$
\end{tabular} & $\begin{array}{l}\text { Dehydartion } \\
\text { No \% }\end{array}$ & $\begin{array}{c}\text { Abdominal pain } \\
N \%\end{array}$ \\
\hline Norovinus & 16 & $15 \quad 94 \%$ & $1169 \%$ & $50 \%$ & $531 \%$ \\
\hline
\end{tabular}

Vomiting: $X^{2}=87.4 \mathrm{df}=4 \mathrm{P}=0.01$ Fever: $\mathrm{X}^{2}=69.37$ $\mathrm{df}=4 \mathrm{P}=0.01$

Dehydration: $\mathrm{X}^{2}=72.41 \mathrm{df}=4 \mathrm{P}=0.01$ Abdominal pain: $\mathrm{X}^{2}=61.87 \mathrm{df}=4 \mathrm{P}=0.01$

\section{Discussion}

Noroviruses has shown to be an important agent of sporadic gastroenteritis in the developed part of the world $^{15}$, however, little or nonexistence of epidemiological information available on burden of the disease associated with sporadic norovirus infection in clinical or hospitalized patients in developing countries $^{16,17}$. It is interesting to state here that this is the first report on norovirus in hospitalized children with gastroenteritis in Basrah, Iraq. The prevalence of norovirus was $8 \%$ in this study. Reviewing the results of recent studies in which molecular methods were applied for detection of enteric viruses, showed that noroviruses accounted for approximately $12 \%$ (range 4.4-30.7\%) of severe gastroenteritis cases among children $<5$ years of age worldwide ${ }^{18}$. However, prevalence as high as 48.4 and $53 \%$ have also been reported in Italy and Australia, respectively ${ }^{15,19}$. In Brazil, two studies conducted on hospitalized children revealed $8.6 \%$ of norovirus infection in two cities in the West Central region ${ }^{20}$; and a prevalence of $20 \%$ in Rio de Janeiro ${ }^{16}$. In United States, Simpson et al. ${ }^{21}$ showed that Norovirus was responsible for $13 \%$. In Korea, Koh et al. ${ }^{22}$ showed that noroviruses were detected in $36.2 \%$ which are higher than our figure.In Tunisia, norovirus was detected in $17 \%$ of fecal samples collected from children with acute diarrhea ${ }^{23}$. Study of pediatric gastroenteritis in Saudi Arabia documented norovirus infection in $3.5 \%$ of children ${ }^{24}$, which is below the $8 \%$ rate identified in this study. The Saudi Arabian study used an ELISA method, which is less sensitive than the RT-PCR used in this study. The variation in detection rates can be attributed to differences between the populations, variations in the time of the study or to the laboratory tests used.Norovirus is often not considered as a cause of serious disease. However, norovirus was found in $8 \%$ of the hospitalized children. The role of norovirus as an important cause of gastroenteritis requiring hospitalization in children has also been reported for other countries such as Italy, Spain, Australia and Russia ${ }^{15,19,25,26}$. We thought the percentage of norovirus is higher than $8 \%$ because only inpatients and the patients who needed hospitalization were supposed to have more severe symptoms were included in this study. Most children with norovirus infections had a lower score of disease severity ${ }^{27}$, so the results from the present study may underestimate the role of norovirus in children less than 5 years of age with acute gastroenteritis in Basrah, Iraq.Data from the present study, suggest that norovirus is a common viral agent causing childhood diarrhea in Basrah. This study improves our epidemiological knowledge about the prevalence of this virus in Basrah and Iraq. Many studies showed that norovirus plays an important etiological role in sporadic diarrhea in infants and young children ${ }^{18,28}$. We found that norovirus-associated diarrhea occurred mainly in children aged 2 years or younger. Our finding is in agreement with studies from Spain, Japan, and India ${ }^{29,30}$. Other study found the peak incidence of norovirus infection among children aged 1-2 years. This is not surprising as this is the age group in which children are usually wean from maternal antibody and introduced to semisolid foods which may be contaminated due to improper handling. Likewise, it is the period in which they crawl around picking anything they see into the mouth. Norovirus was detected in both genders with no significant difference. 
A similar occurrence of these viruses in male and female children in different age groups is described in other studies 31,32 . In many countries, norovirus infection is prevalent in winter months 4 , and several studies showed no seasonal distribution 33,34 . In this study Norovirus infection occurs year-round except May and October while a higher number of rotavirus cases were detected in these months. We observed a peak of noroviruses detection in fall and winter, which is consistent with the results of other studies1. As others had found in studies of similar populations16,34, they noticed that norovirus was detected throughout the year and more commonly during the summer months. However, the season prevalence of norovirus infection was highly variable in different regions as shown in some studies35,36.Vomiting is more common in children with norovirus infection is similar to other study37. Delay in gastric emptying may be responsible for the vomiting associated with this agent 3 . As well as diarrhea the most common clinical symptoms present were vomiting (94\%) and fever( 69\%) which is in agreement with those from other studies 38 .However, our results are in contrast with those reported children infected with norovirus at a hospital in Rio de Janeiro where vomit observed in $33.3 \%$ of the cases 16 .

\section{References}

1. Medici MC, Martinelli M, Abelli AL etal. Molecular epidemiology of norovirus infection Sporadic cases of viral gastroenteritis among children in Nothern Italy.

J Med Virol 2006, 78(11): 1486-1492.

2. Van Duynhoven YT, de Jager CM, Kortbeek LM, et al. . A one-year intensified study of outbreaks of gastroenteritis in The Netherlands. Epidemiol Infect 2005, 133(1):9-21.

3. Kapikian AZ. . Viral gastroenteritis. In: Goldman L, Ausiello D, eds. Cecil Textbook of Medicine, 22nd edition. Philadelphia: Saunders,2004 pp 2015-20.

4. Hedlund, K. O., Rubilar-Abreu E., and Svensson L.. Epidemiology of calicivirus infections in Sweden, 1994-1998. J Infect Dis 2000, 181: Suppl 2:S27580.

5. Lopman B.A., Brown D.W., Koopmans M . Human caliciviruses in Europe. Journal of Clinical Virology 2002, 24: 137-160.

6. Koopmans, M., and Duizer E. Foodborne viruses: an emerging problem. International Journal of Food Microbiology 2004,90:23-4

7. Beuret, C., A. Baumgartner, and J. Schluep. Viruscontaminated oysters: a three-month monitoring of oysters imported to Switzerland. Appl Environ Microbiol 2003,69:2292-7.

8. Borchardt, M. A., Haas N. L., and Hunt R. J. Vulnerability of drinkingwater wells in La Crosse, Wisconsin, to enteric-virus contamination from surface water contributions. Appl Environ Microbiol 2004, 70:5937-46.

9. Cheng, P. K., Wong D. K., Chung T. W., and Lim W. W. Norovirus contamination found in oysters worldwide. J Med Virol 2005,76:593-7.

10. Moreno-Espinosa S, Farkas T, Jiang X. Human caliciviruses and pediatric gastroenteritis. Semin Pediatr Infect Dis 2004, 15(4):237-45.

11. Rabenau, H. F., Sturmer M., Buxbaum S., Walczok A., Preiser W., and Doerr H. W. Laboratory diagnosis of norovirus: which method is the best? Intervirology 2003, 46:232-8.

12. Vinje, J., Vennema H., Maunula L., von Bonsdorff C. H., Hoehne M., Schreier E., Richards A., Green J., Brown D., Beard S. S., Monroe S. S., de Bruin E., Svensson L., and Koopmans M. P. International collaborative study to compare reverse transcriptase PCR assays for detection and genotyping of noroviruses. J Clin Microbiol 2003,41:1423-33.

13. World Health Organization, Department of Immunization, Vaccines and Biological. Manual of rotavirus detection and characterization methods. CH-1211 Geneva 27, Switzerland 2009.

14. Romani S., Azimzadeh P., Mohebbi S. R., Bozorgi S. M., Zali N., Jadali F. Prevalence of sapovirus infection among infant and adult patients with acute gastroenteritis in Tehran, Iran.Gastroenterol Hepatol Bed Bench.2012, 5(1): 43-48.

15. Kirkwood CD, Clark R, Bogdanovic-Sakran N, Bishop RF . A 5-year study of the prevalence and genetic diversity of human caliciviruses associated with sporadic cases of acute gastroenteritis in young children admitted to hospital in Melbourne, Australia (1998-2002). J Med Virol 2005, 77 (1):96-101

16. Victoria, M., Carvalho-Costa F. A., Heinemann M. B., Leite J. P., and Miagostovich M. 2007. Prevalence and molecular epidemiology of noroviruses in hospitalized children with acute gastroenteritis in Rio de Janeiro, Brazil,. Pediatr. Infect. Dis. J. 2004, 26:602-606.

17. Armah GE, Gallimore CI, Binka FN, Asmah RH, Green J, Ugoji U, Anto F, Brown DWG, Gray JJ. Characterization of Norovirus Strains in Rural 
Ghanaian Children with Acute Diarrhoea. J. Med. Virol.2006, 78: 1480-1485.

18. Patel, M. M., Hall A. J., Vinje J., and Parashar U. D. Noroviruses: a comprehensive review. J Clin Virol 2009,44:1-8.

19. Colomba, C., Saporito L., Giammanco G. M., De Grazia S., Ramirez S., Arista S., and Titone L.. Norovirus and gastroenteritis in hospitalized children, Italy. Emerg Infect Dis 2007,13:1389-91.

20. Borges AM, Teixeira JM, Costa PS, Giugliano LG, Fiaccadori FS, Franco RC, Brito WM, Leite JP and Cardoso DD.. Detection of calicivirus from faecal samples from children with acute gastroenteritis in the West Central region of Brazil. Mem. Inst. Oswaldo Cruz 2006, 101: 721-724.

21. Simpson R, Aliyu S, Iturriza-Gomara $\mathrm{M}$, Desselberger U, Gray J. Infantile viral gastroenteritis: on the way to closing the diagnostic gap. J Med Virol 2003, 70: 258-62.

22. Koh H, Baek SY, Shin JI, Chung KS, Jee YM. Coinfection of viral agents in Korean children with acute watery diarrhea. J Korean Med Sci. 2008, 23(6):937-40.

23.Sdiri-Loulizi K, Gharbi-Khélifi H, de Rougemont A, Chouchane S, Sakly N, Ambert-Balay K, et al. Acute infantile gastroenteritis associated with human enteric viruses in Tunisia. J Clin Microbiol 2008,46: 134955.

24. Tayeb HT, Dela Cruz DM, Al-Qahtani A, Al-Ahdal MN \& Carter MJ .Enteric viruses in pediatric diarrhea in Saudi Arabia. Journal of Medical Virology 2008, 80, 1919-1929.

25. Lorrot M, Bon F, El Hajje MJ, Aho S, Wolfer M, Giraudon $\mathrm{H}$ et al.. Epidemiology and clinical features of gastroenteritis in hospitalised children: prospective survey during a 2-year period in a Parisian hospital, France. Eur J Clin Microbiol Infect Dis 2011, 30 (3):361-368.

26. Podkolzin AT, Fenske EB, Yu Abramycheva N, Shipulin GA, Sagalova OI, Mazepa VN et al. . Hospital-based surveillance of rotavirus and other viral agents of diarrhea in children and adults in Russia, 2005-2007. J Infect Dis 2009, 200:S228-S233

27. Siebenga, J. J., Vennema H., et al. . "Gastroenteritis caused by Norovirus GGII.4, The Netherlands, 1994- 2005." Emerging infectious diseases 2007,13(1): 144-146.

28. Ramani, S. and Kang, G. . Viruses causing childhood diarrhea in the developing world. Curr. Opin. Infect. Dis. 2009, 22, 477-482.
29. Junquera, C.G., de Baranda, C.S., Mialdea, O.G., et al. . Prevalence and clinical characteristics of norovirus gastroenteritis among hospitalized children in Spain. Pediatr. Infect. Dis. J.2009, 28, 604-607.

30. Okame, M., Akihara, S., Hansman, G., et al. . Existence of multiple genotypes associated with acute gastroenteritis during 6-year survey of norovirus infection in Japan. J. Med. Virol.2006, 78, 1318-1324.

31. Jalilian S., Samarbaf-Zadeh A. R., Mozhgani S. H. R., Makvandi M., Parsa-nahad M., Pirmoradi R., Shamsi-Zadeh A. . Relative Frequency of Norovirus Infection in Children Suffering From Gastroenteritis and Referred to Aboozar Hospital, Ahvaz, Iran. Jundishapur J Microbiol. 2012,5(1):355-358.

32. Ayolabi C. I., Ojo D. A., Armah G. E., Akpan I. and Mafiana C. F.. Detection and partial characterization of norovirus among children with acute gastroenteritis in Lagos, Nigeria. International Journal of Medicine and Medical Sciences 2010, 2(7) : 216-221.

33. Nakata, S., Honma S., Numata K., Kogawa K., Ukae S., Adachi N., Jiang X., Estes M. K., Gatheru Z., Tukei P. M., and Chiba S. Prevalence of human calicivirus infections in Kenya as determined by enzyme immunoassays for three genogroups of the virus. J Clin Microbiol 1998,36:3160-3.

34. O'Ryan ML, Mamani N, Gaggero A,Avendano LF, Pena A, Jiang X, Matson DO. . Human caliciviruses are a significant pathogen of acute sporadic diarrhea in children of Santiago, Chile. J Infect Dis 2000,182: 1519-1522

35. Cheryl S.Y.Li, Paul K.S. Chan, and Julian W. Tang. . Prevalence of diarrhea viruses in hospitalized Children in Hong Kong in 2008. J Med Virol; 2009,81:1903-11.

36. Xu J, Yang Y, Sun J, Ting Y. . Molecular epidemiology of norovirus infection among children with acute gastroenteritis in Shanghai, China, 2001-2005. J Clin Virol 2009, 81:1826-30.

37. Mattner F, Sohr D, Heim A, Gastmeier P, Vennema $\mathrm{H}$, Koopmans M. . Risk groups for clinical complications of norovirus infections: an outbreak investigation. Clin Microbiol Infect 2006, 12:6974.

38. Rockx, B., De Wit M., Vennema H., Vinje J., De Bruin E., Van Duynhoven Y., and Koopmans M. . Natural history of human calicivirus infection: a 
prospective cohort study. Clin Infect Dis 2002,35:246-53.

39. Green J, Gallimore CI, Norcott JP, LewisD,BrownDW. . Broadly reactive reverse transcriptase polymerase chain reaction for the diagnosis of SRSV-associated gastroenteritis. J Med Virol 1995,47: 392-398. 